\title{
DUTCH COLONIAL AND INDONESIAN \\ NATIONALIST POLICIES TOWARD THE CHINESE MINORITY IN INDONESIA
}

\author{
By Mary F. Somers Heidhues
}

\section{Administration of the Chinese under the VOC (1619-1800)}

Men of the Dutch East India Company (Vereenigte Oost-Indische Compagnie or VOC) had one clear purpose in attempting to lure Chinese settlers to their harbor, Batavia, in the 17th century: to further trade. Having observed the skill and industry of that nation as traders, pepper-and rice-growers in the native sultanate of Bantam, Batavia's rival at the western tip of Java, the Netherlanders hoped that a strong Chinese element would do as much for the newly-founded Batavia, established on the site of the conquered town of Jacatra in 1619.

Their policy was a succes, for the 400 Chinese living in the port in 1619 grew to nearly 2000 a decade later. For these settlers, the Dutch chose a system of governance with ample precedent in eastern Asia, appointing a Kapitan China (to use the most widespread, Malay designation for the office), a headman or "Captain" of the Chinese. From the example of the Portuguese in Malacca, the VOC had learned to prescribe for the Chinese (and other alien groups) their own residential yuarter, camp or Kampong, their own dress, and their own headmen. The Kapitan system, however, antedated European colonial rule in Asia. Indigenous rulers who presided over substantial numbers of foreign resident traders, be they in 17 th century Siam-Ayudhya, in the Khmer kingdom of the 18 th century, or on the Malay peninsula in the 19th century, managed these alien elements through headmen from that group. The Dutch were in contact with Kapitans China in Kobe, Japan, in the 17 th century ${ }^{1}$. Evidence suggests that even in China itself, under the Ming dynasty, foreigners residing in the southern ports were subject to a similar system ${ }^{2}$. Given the heterogeneous populations of the Asian trading ports in this era, the rulers, be they indigenous or European, preferred to leave the internal policing of the foreign communities to a person chosen from the community who enjoyed its respect and that of the rulers as well.

In addition to the Kapitan system, which was used in the Spanish Philippines, as well as in the places mentioned above, subjugation to a head-tax, instead of some kind of tribute or tax in kind as was paid by the peasants, frequently characterized the special postion of the alien traders. In the Indies, the head tax paid by individual Chinese was greater than the tax paid by natives.

Batavia's first Chinese Kapitan, So Bing Kong, or Bencon as the Dutch called him, probably differed little from the type of Kapitan known in the indigenousruled ports of Southeast Asia. The most "prominent", that is, the wealthiest, of

1 On Batavia's first Kapitan China, see B. Hoetink, "So Bing Kong: Het eerste Hoofd der Chineezen te Batavia," Bijdragen tot de Taal-, Land- en Volkenkunde van Nederlandsch-Indie, 1917, pp. 342-414 and 1923, pp. 1-44. On the Kapitan system in Southeast Asia, see the remarks of G. William Skinner, "O23, pp. 1-44. On the Kapitan system in Southeast Asia, see the remarks of G. William Skinner,
"Overseas Chinese Leadership: Paradigm for a Paradox", in G. Wijeyewardene, ed., Leadership and Authority (Singapore: University of Malaya Press, 1968), pp. 191-207. It should be noted that the system of Kampongs mentioned here was not strictly enforced and many Chinese, legally or illegally, settled in the lands around Batavia as well.

2 C. S. Wong, Gallery of Chinese Kapitans (Singapore: Ministry of Culture, 1963), p. ii. 
Batavia's Chinese, he was installed months after the founding of the city, charged with insuring "good order" among his countrymen, authorized to maintain the civil register and to settle civil cases within the group, referring the more serious disputes, either criminal offenses or disputes involving nonChinese, to the Dutch authorities. His advice was also sought on other matters affecting the Chinese ${ }^{3}$. Finally he concerned himself with the general welfare of the group.

Almost equally significant were the subsidiary trappings of the Kapitans. In addition to being personally wealthy, like So Bing Kong, they used their connections with the authorities to gain additional favors in trade, title to land in the area around the port or control of one of the revenue monopolies for the production or sale of restricted commodities. In addition, the Kapitan and certain members of his household were exempt from the head-tax. In the 19th century, this system of symbiosis reached its peak. So Beng Kong's successors also affected Mandarin dress as a sign of their exalted status and staged elaborate public processions at their installation. Some of them made great fortunes from the monopoly of opium. At least one 18th century Kapitan had the power to recommend undesirables for deportation.

The problem of assimilation showed great differences in various parts of Southeast Asia. Historical data indicates that the grandchildren of Chinese immigrants to Siam were, until the early years of this century, completely assimilated into Thai society. In other Southeast Asian lands, for example Cambodia and the Philippines, Chinese were also absorbed into the local population. By contrast, descendants of Chinese immigrants to Java remained "Chinese" for generations; one source traces the family of So Bing Kong, for instance, to the fifth generation". If So's family is not an isolated example, and it appears not to be, what peculiar conditions retarded assimilation of the Chinese in Java in this period?

At the top of the list of factors affecting assimilation of Chinese stands the fact that the social hierarchy imposed under colonialism retarded assimilation of Chinese in Java. Assimilation to Thai society was attractive to Chinese in Siam because the Thai were the ruling elite. How different was the status of the native in Dutch-ruled Java! The ruling Dutch elite was closed to the Chinese, but the native was, in the coastal towns, far below the Chinese on the social scale. What we know of Chinese in the native-ruled states of Java (only the tiny principalities in Central Java, in and around Jogjakarta and Surakarta, existed after 1757) indicates how important this difference was. Chinese in the Javanese-ruled principalities strove to emulate the rulers there and cultivated good relations with them. Their Kapitans were happy to receive titles of nobility and other indications of favor from the indigenous elite.

Second in importance, and closely related to the social position of the Chinese within the indigenous society, is intermarriage. Since women did not emigrate from China before the 20th century, Chinese traders and artisans residing for extended periods in the Nanyang (as they called Southeast Asia) often took local brides. Indigenous women, of course, were valuable partners for businessmen, for they facilitated contact with indigenous customs and customers. Daughters

3 Material on the Kapitans under the VOC is drawn from Hoetink, loc. cit., and the same author's "Chineesche officieren te Batavia onder de Compagnie," Bijdragen tot de Taal-, Land- en Volkenkunde van Nederlandsch-Indie, 1922, pp. $1-136$

4 According to Souw (So) Bi Enko, himself a great-grandson of Bencon, in a chronicle written in 1758 and cited by Hoetink (1923), p. 3. 
of such mixed unions in 19th century Siam, for example, grew up under their mothers' influence and some of them, if their fathers were interested in expanding their influence, might marry into the Thai aristocracy. The pull of Thai society was so strong that the daughters of Thai-Chinese marriages and if not the sons, the grandsons, were completely assimilated to Thai life ${ }^{5}$.

The situation in the Dutch colony differed from that in Siam in several, significant ways. Many of the early Chinese settlers in Batavia had wives or concubines from a native non-Islamic group, for example Balinese. In view of their relatively low position in the society of the port cities, these women could not be the force for assimilation that their counterparts in Siam were. On the contrary, many offspring of Chinese settlers and local women appear to have grown up within the local Chinese society. Among the upper classes, that is, the Chinese officers, Kapitans and lieutenants (the rank having been established to assist the Kapitans or to govern the smaller Chinese settlements) there seems to have been resistance to intermarriage. Although one of So's successors married a Balinese, the records of the 18th century are replete with examples of the marriage of Chinese Kapitans or lieutenants of one or another Javanese coastal city with the daughters of other Chinese officers ${ }^{6}$.

The fact that women of mixed descent, at least in the upper class, were retained in Chinese society greatly retarded assimilation.

Another contrast between Thai and Javan societies was in the religion of the indigenous inhabitants. Adoption of Theravada Buddhism, as practiced in Siam, was a relatively easy matter for a Chinese, requiring no dramatic break with his former religious practices. Islam, however, demanded of a Chinese conversion, circumcision, and abstinence from pork. Furthermore, the law of the colony stipulated that Chinese remain identifiably Chinese (whereas in Siam the laws provided for a process of legal assimilation), not least because natives paid less taxes. Conversion to Islam was not normally considered proof of assimilation to native society. Dutch sources from the 17 th and 18 th century refer to "shaven" or Moslem Chinese, but the VOC only grudgingly recognized them as "natives".

\section{The Peranakan Chinese}

At the latest, by the early 19th century, Java had a stable, self-perpetuating Peranakan $^{7}$ Chinese society. Calling themselves Chinese and retaining Chinese surnames, albeit of mixed blood, the Peranakans did not use a Chinese language but spoke as mother tongue Malay or another indigenous language, sprinkled with a few Hokkien ${ }^{8}$ Chinese expressions, in particular kinship terms. Furthermore, they had adopted many features of the dress, eating habits and in particular the pre-Islamic or syncretistic religious practices of the indigenous people.

\footnotetext{
5 19th century Siam was a Southeast Asian society extremely receptive to assimilation of Chinese immigrants and their descendants, according to G. William Skinner, Chinese Society in Thailand: An Analytical History (Ithaca: Cornell University Press, 1957). The same author has compared the situation in Siam with that in Java in "Change and Persistence in Chinese Culture Overseas: A Comparison of Thailand and Java," Journal of the South Seas Society, 1960, pp. 86-100. A further source is The Siauw Giap, "Religion and Overseas Chinese Assimilation in Southeast Asian Countries," Révue du Sud-Est Asiatique, 1965:2, pp: 67-83.

6 Hoetink (1922) mentions several such matches. The Siauw Giap (loc. cit., p. 72) insists that in 1717 Chinese were forbidden to marry non-Chinese, but does not mention the source of this regulation.

7 Peranakan, from the Malay roat word anak, child, means a local-born and locally-rooted person of foreign ancestry.

8 Hokkien refers to that Chinese language group which came from the neighborhood of Amoy in Fukien province. Since the vast majority of Chinese who migrated to Java before the end of the 19th century were Hokkiens, most Peranakans are of Hokkien ancestry. Other speech groups from southeastern China were more strongly represented in the settlements outside Java.
} 
This Peranakan group, which existed in Java, other parts of the archipelago, and on the Malay peninsula, appears to have been unique in Southeast Asia. In Cambodia, ability to speak Chinese was the minimal qualification for being regarded as Chinese ${ }^{9}$. Elsewhere, descendants of mixed Chinese-native unions, even tough they had a separate legal status, such as the Chinese Mestizos in the Philippines and the Minh-huong in Vietnam, were regarded as "a special kind of native" and not as "a special kind of Chinese". Both these groups melted into native society, Chinese Mestizos in the Philippines becoming part of the new, national Filipino elite by the end of the 19th century ${ }^{10}$.

Although Peranakan society was stable and self-perpetuating in the 19th century, some Chinese continued to be "lost" through assimilation to indigenous society. First of all, outside the major concentrations of Chinese settlement along Java's north coast, there was less possibility of remaining Chinese over several generations because the numbers of Chinese were insufficient for self-perpetuation. Second, where Islam was strictly orthodox, as in Madura and parts of Sumatra, conversion to Islam was a prerequisite to female companionship; intermarriage resulted in the absorption of the offspring into indigenous society. Finally, many second- and thirdgeneration Chinese of the lower classes, even in the Dutch-ruled coastal towns, probably melted into indigenous society - a process which took place without record or fanfare. Their poverty made it impossible for them to maintain the outward signs of Chineseness.

The situation of the Chinese outside Java displayed more diversity. As mentioned above, in strongly Islamic areas, Chinese may have been converted and assimilated to the local population. In other areas, the pattern approached the Peranakan one. Unique was the situation in the Kongsis ${ }^{11}$ of West Borneo. In this area, which came under Dutch rule only in the middle of the 19th century, substantial numbers of Chinese settled as gold miners and farmers. They lived in virtually autonomous communities and married local Dayak (pagan) women. Evidence of the strength and persistence of their society is that the women learned to speak Chinese; the descendants of this group have maintained the Chinese language to this day.

\section{The 19th Century: New Forces Undermine Old Institutions}

During the 19th century, additional regulations distinguished Chinese or "foreign orientals", as they, together with the smaller minorities of Arab or Indian origin, were called, from the natives; most important of these were the pass- and quarter-systems and the agrarian laws. After 1816, foreign orientals had to obtain a pass when traveling outside the major cities and towns. In 1835, the administration established special residential quarters (like the Kampongs of the VOC) for Chinese, although the system was only gradually put into force. The agrarian laws in 1854 forbade the alienation of agricultural land to non-natives, although land already in Chinese hands, especially the so-called private lands, remained untouched ${ }^{12}$.

9 William E. Willmott, The Chinese in Cambodia (Vancouver: University of British Columbia, 1967). The Chinese community was organized by speech group; those who spoke Chinese could not have been accomodated.

10 Edgar Wickberg, The Chinese in Philippine Life, 1850-1898 (New Haven: Yale University Press, 1965) describes this process in detail.

11 Kongsi, from the Mandarin kung-ssu, means a cooperative undertaking, a business company. The Kongsis of West Kalimantan or Borneo were self-governing farming and mining undertakings. For a recent study on the subject, see James C. Jackson, Chinese in the West Borneo Goldfields: A Study in Cultural Geography. (Hull: University of Hull Occasional Papers in Geography No. 15, 1970).

12 See Wouter Brokx, Het recht tot wonen en tot reizen in Nederlandsch-Indie ('s-Hertogenbosch: Teulings' Koninklijke Drukkerijen, 1925) pp. 29 and 183, and R. R. Ardiwilaga, Hukum Agraria Indonesia (Bandung-Djakarta: Masa Baru, 1960), pp. 123, 125, 137-139. 
And what of the Kapitans? The record of the 19th century shows that this institution had acquired permanence and a certain authority of its own. The power the Kapitans had stemmed not alone from their office, but from their wealth, which was a prerequisite to office. Chinese officers (those in larger cities were soon dubbed Majoor, with a staff of lesser officers to aid them, in small towns a Lieutenant sufficed) needed wealth to be able to perform as both the Chinese and the colonial authorities expected them to do; their office in turn provided opportunity for enrichment. For the most part, the officers came from the established Peranakan families of Java.

Toward the end of the 19th century, however, new forces felt in virtually all Chinese settlements in Southeast Asia touched the Netherlands Indies. On the one hand, immigration from China increased almost geometrically in the last decades of the century. Although many of these were "coolies" who worked on the mines and plantations of Sumatra, thousands came to Java each year. The cultural baggage of the new arrivals, their language, religion, dress, and other customs impressed and shamed the culturally bastardized Peranakans, confronting them with an example of what "being Chinese" really meant in the homeland. What is more, the immigrants were too numerous to be absorbed by the Peranakans. The arrival of sizable numbers of Chinese women in the 20th century enabled the perpetuation of a pure or "Totok" ${ }^{13}$ " Chinese society in the Indies. Nor did the influence from the homeland remain purely cultural; both the Manchu regime and its revolutionary opponents led by Sun Yat-sen, as well as the various governments of China after 1911, attempted to draw the Chinese in Southeast Asia into their political and economic sphere of influence. Modern methods of communication, from the steamship to the daily newspaper, helped China increase her contact with the Overseas Chinese abroad. The early 20th century was for all ethnic Chinese ${ }^{14}$ in Southeast Asia, not least those in the Indies, a period of development of homeward-looking political consciousness, of minority, Overseas Chinese, nationalism, as Williams so aptly terms it ${ }^{15}$.

That the Kapitan China system was no longer suitable to cope with this newly heterogeneous and self-confident minority appears obvious. First of all, it could no longer regulate internal community affairs. To mention one of their more serious difficulties, most officers, speaking little Chinese, could not communicate with the Totoks. Second, the system was no longer needed as middleman by the colonial regime, for the laws governing Chinese were gradually so modified as to make the officers superfluous as agents of the administration. The pass- and quarter-systems were abolished; Chinese were brought under European commercial law. The attempts of the colonial regime to shore up the crumbling prestige of the officers tended to make their position ludicrous: the provision of Europeanstyle military uniforms for the Kapitans only emphasized their alienation from their Chinese constituency ${ }^{16}$.

13 Totok, Malay-Indonesian for pure, is used for foreign-and local-born Chinese who speak Chinese and adhere to a culturally Chinese style of life. Foreign-born Chinese are also often called Sinkeh, from the Mandarin hsin-k'e, new arrival.

14 Ethnic Chinese refers here to those, both Totok and Peranakan, regarding themselves as Chinese and so regarded by those around them, in practice, it is virtually equivalent to those bearing Chinese surnames in the case of Indonesia.

15 Lea E. Williams, Overseas Chinese Nationalism: The Genesis of the Pan-Chinese Movement in Indonesia, 1900-1916 (Glencoe: The Free Press for Massachusetts Institute of Technology, 1960).

16 Williams, op. cit., p. 128. 


\section{Dutch Policy and Chinese Response: the 20th Century to 1945}

If Dutch policy toward the Chinese in the 17 th century was governed by the idea of utilizing them to improve trade, what were the considerations in the early 20th century? In the islands less densely populated than Java, Chinese immigrants were welcomed as coolie laborers until diminishing raw material prices in the 1920's forced a cutback in economic activity and a reduction of immigration. On Java, petty traders, many of them Chinese immigrants, contributed to the development of such inland areas as the Priangan in West Java, where they collected native-produced raw materials from the interior and, through their network of business connections, delivered them to Chinese- and European-owned exports firms. But the Chinese presence was not viewed as merely beneficial. The so-called "Ethical Policy", which attempted to improve the position of the indigenous peoples, sought to curb the economic power of the Chinese, whose business practices were blamed for the "diminishing welfare" of the native. Monopoly and revenue privileges were for the most part abolished, and the government held firm to the prohibition against Chinese obtaining title to native agricultural land, out of fear that the natives would be stripped by Chinese moneylenders of all their property. On the other hand, other considerations prompted the Dutch to be conciliatory toward Chinese interests. Among these was the fear that the Chinese, many of whom were infected with nationalist ideas at the onset of the century, might make common cause with the native nationalists, who became active only about 1910 with the founding of the first nationalist organizations, above all the Sarekat Islam. The thrust of colonial policy, then, was to offer conciliation to the Chinese in order to associate them with the Dutch regime, yet never completely to assimilate them to it. The hope of some Western-educated Chinese of being placed on an equal footing with Europeans in the legal system (as the Japanese had been) was never fulfilled.

Indicative of the Chinese response is the new leadership which came to the fore, replacing the Kapitans. These leaders came from the many voluntary associations founded about the turn of the century. Of these, two stand out, the Siang Hwee (Mandarin Shang-hui, chamber of commerce) and the Tiong-Hoa Hwe Koan (Chung-hua Hui-kuan, Chinese association) ${ }^{17}$.

Wealth was still the key to prestige among the Chinese minority in the 20th century and the Siang Hwees or Chambers of Commerce, organized in imitation of similar European institutions in the major cities and towns of Southeast Asia, united individuals of wealth, in the case of Java both Totok and Peranakan, and their businesses. In some cases actually initiated by representatives of the China mainland government, they were founded in the first decade of this century. The Chinese governments recognized the Siang Hwees as the arbiter of Overseas Chinese affairs; under the Republic of China, the Chambers were to choose the representatives of the Overseas Chinese in the homeland's parliament. Where there was no Chinese consulate, the Siang Hwee performed consular functions. Thus the organization played both economic and political roles. In some areas,

17 Mandarin equivalents are given for these and other expressions which, following the usage current in the Indies at the time, are in the Hokkien Chinese pronunciation. Mandarin or kuo-yu titles for Chinese organizations later became common, as, thanks to the movement for modern Chinese education, more ethnic Chinese in the Indies learned to speak Mandarin. 
there was also a national organization of the Chambers; in the Indies, with one brief exception, the Siang Hwees were organized on a local basis only ${ }^{18}$.

The Tiong Hoa Hwe Koan (THHK), on the other hand, began as a Confucianist religious organization which attempted to purge Peranakan customs of Javan accretions; subsequently it became the locomotive of modern, Chinese-language education in Java. The association did so at a time when education, and especially modern education, acquired great importance among Chinese abroad, who up to that time had known only the old-fashioned schools for memorization and recitation of the Classics or Western schools run primarily for Europeans ${ }^{19}$. In the smaller towns, were no Siang Hwee existed, the board of the THHK school of ten was identical with the leadership of the local Chinese community. Nor were the THHK and the Chamber of Commerce mutually exclusive; on the contrary, the school boards needed the financial and moral support of the wealthy businessmen. In the cities, Siang Hwee and THHK leadership of ten overlapped.

Modern Chinese schools themselves experienced a mushroom growth; by 1908 there were 75 such schools in the Indies with 5500 pupils. In 1930, they are estimated to have been 30,000 children in such schools ${ }^{20}$, offering instruction in Kuo-yu or Mandarin, the Chinese national language and a foreign language to both Totok and Peranakan children in the Indies, the former being speakers of one of the southern Chinese languages, the latter speaking Malay or another Indonesian language. The subject matter followed closely that of the modern schools in China, and the political content thereof was highly nationalistic and often anti-Western.

Meanwhile, colonial policy worked to split the Chinese community irrevocably. One manifestation was the extension of Dutch subjectship to local-born Chinese in 1910, months after the revised law code in China recognized all Chinese born abroad and their descendants as Chinese nationals. Even more significant was the opening of prestigious Dutch-language education to ethnic Chinese (only a handful of whom had been admitted to Dutch-language schools previously) through the Hollandsch-Chinesische Schoolen or Dutch-Chinese schools, in 1908. What had been the prerogative of the very few, the children of Chinese officers and a few others who had received private instruction in Dutch, became available to the entire Chinese community. This concession was granted six years before similar institutions made Dutch-language education available to sizable numbers of native Indonesians. In the decade before World War II, the majority of ethnic Chinese children who attended school attended Chinese-language schools, but the majority of Peranakan Chinese schoolchildren were in Dutch-language schools. Because they were better able to continue their education at secondary and tertiary level (university education in Chinese was available only in China), the Dutch-educated gradually assumed the leadership of the Peranakan Chinese and, thanks to their superior education and familiarity with the Dutch system, in many instances they became spokesmen for the entire Chinese community.

Japanese occupation (1942-1945) policy toward the Chinese minority, which cannot be detailed here, had several special features. First, the Chinese were cut off from Dutch influence, either in schools or through personal contact, for the

18 Williams, op. cit., pp. 95-99 and 103.

19 On the Tiong Hoa Hwe Koan, see Williams, op, cit., passim and Nio Joe Lan, Riwajat 40 Taon darı Tiong Hoa Hwe Koan-Batavia (Batavia: THHK Drukkerij, 1940).

20 Figures from the Dutch Adviser for Chinese Affairs. On education of ethnic Chinese in the Indies, see the author's Peranakan Chinese Politics in Indonesia (Ph. D. Thesis, Cornell University, 1965), Chapter II. 
schools were closed and Dutch citizens interned. Secondly, the occupation drew Peranakans and Totoks closer together, partially closing the gap formed in the 1920's and 1930's. Third, the Japanese period gave great impetus to Indonesian nationalism, a movement from which the ethnic Chinese were almost completely excluded. The institutions in the Chinese community which developed under Japanese rule soon vanished, but the influence of these three changes persisted for several years, despite the reestablishment of Dutch authority in the cities after 1945 and the final recognition of Indonesian independence in December 1949.

\section{Independence and the Integration of the Chinese Minority}

Like the Japanese occupation, although for different reasons, the period of the Indonesian Revolution (1945-49) tended to drive the two parts of the Chinese community together. Although the revolutionary Indonesian government sought to conciliate the Chinese, it could not enforce its authority, especially over irregular fighting units and in view of its own scorched earch policy. In a number of incidents involving Indonesians, Chinese suffered loss of life and property and they sought refuge by drawing together, preferably to the comparative safety of the Dutch-controlled cities.

Only in the mid-1950's did a coherent policy of the Indonesian government toward the Chinese minority become evident. Even then, policy and practice contained many contradictions.

On the question of citizenship, these contradictions soon came to the fore. On the one hand, both the first Indonesian citizenship law (1946) and the Round Table Agreement by which the Netherlands recognized Indonesian sovereignty (December 1949) extended citizenship automatically to all former Dutch subjects, as far as the Chinese were concerned, to those born in the Netherlands Indies. On the other hand, those local-born who wished to be Chinese citizens could, within a certain period, reject Indonesian citizenship, a provision which met the grievances of many Chinese "overseas nationalists" who had argued since 1910 that automatic acquisition of Dutch subjectship upon birth in the Indies deprived them of their right to remain Chinese citizens if they so wished. The Chinaborn were, under these laws, Chinese citizens and must remain so; a law on citizenship in 1958, although it permitted aliens the possibility of naturalization, in practice allowed few if any alien Chinese to become Indonesian citizens ${ }^{21}$. As a result, the Chinese minority included a large, alien hard core, which could be expected to be unassimilable and virtually impossible to integrate in Indonesian society.

The mid-1950's actually witnessed a retreat from the generous policy on Indonesian citizenship for the local-born. Indonesian citizenship was to admit as small a number of ethnic Chinese as possible, by requiring additional qualifications for citizenship. Indicative of this standpoint was the Indonesian cabinet's position on the Dual Nationality Treaty signed with the People's Republic of China in 1955. In this treaty, the Chinese government recognized (for the first time) that Indonesian citizens of Chinese descent should not have Chinese nationality as well.

21 The best source on Indonesian nationality policy up to about 1958 is Donald E. Willmott, The National Status of the Chinese in Indonesia, 1900-1958 (Ithaca: Cornell Modern Indonesia Project, Monograph Series, 1961). 
The Indonesian negotiators insisted, however that such "dual nationals" make an active declaration of their rejection of Chinese citizenship in order to retain the Indonesian citizenship accruing to them from birth ${ }^{22}$.

In fact, Indonesian policy toward the Chinese minority was, at this time, rather schizophrenic. Although it distinguished sharply between citizen and alien, this discrimination was not balanced by equal treatment of all citizens. For example, in distributing permits and privileges for doing business of certain kinds (exportimport or rice-milling, for example), the government gave preference to citizens. But citizens of Chinese descent, readily recognizable because of their Chinese names, were discriminated against in practice. The mid-1950's even witnessed attempts to exclude them from certain business activities, on the grounds, among others, that they were "dual nationals" and not fully loyal to Indonesia. Although this latter policy was later denounced, in practice, a Chinese name and appearance evoked discrimination in most dealings with the authorities.

In addition to dual nationality, other barries to their legal assimilation, and consequently to their social and cultural absorption, remained. The Indonesian governments rejected the policies of the Dutch colonial regime which served to divide the indigenous ethnic groups from one another. The cry, "one land, one people, one language", summed up the goals of Indonesian nationalists since 1926, but the formation of "one people", in the nationalist movement, stopped short of assimilation of the Chinese minority, who remained in the eyes of most indigenous Indonesians "foreign orientals" 23. The prohibition on acquisition of agricultural land (but not on renting or leasing it), legal barriers to the assumption of Indonesian names, and certain other legal barriers to assimilation remained in force until the 1960's. Indonesians in general were of the opinion that these barriers were necessary to "protect" the indigenous from the sharp economic practices of the more experienced and more competitive ethnic Chinese, even though the latter group included a wide spectrum of individuals and types, down to the locally-rooted and local-born Peranakans, some of them with no more business acumen than the average "native" Indonesian.

Another policy of this period was to separate, as far as possible, Indonesian citizens from the influence of China and of the alien Chinese residing in Indonesia. In 1959-60, aliens were forbidden to reside in rural areas in some provinces, a regulation reminiscent of, although not so limiting as, the colonial quarter system. Above all, however, this attitude made itself felt in educational policy. In 1957, the government forbade Indonesian citizens to attend non-national schools. This meant that about 250000 children (according to official estimates) were displaced from Chinese-language schools whose curricula were often directed to training partiots for the new China rather than Indonesian citizens. The number of Chineselanguage or alien schools was drastically reduced, and those remaining were subjected to a number of restrictions, including stricter inspections to rid them of material excessively colored (in Indonesian eyes) by Chinese chauvinsism.

\section{Changes in Policy Since Implementation of the Dual Nationality Treaty}

The People's Republic of China, with which Indonesia had maintained friendly

22 David P. Mozingo, “The Sino-Indonesian Dual Nationality Treaty," Asian Survey, December 1961, pp. $25-31$.

23 See Leo Suryadinata, "Pre-War Indonesian Nationalism and the Peranakan Chinese", Indonesia, April 1971, pp. 83-94. 
relations from before the Bandung Conference (1955) until 1965, despite a disagreement after the attack on the position of Chinese nationals in rural retail trade in 1959-6024, implemented the Dual Nationality Treaty with Indonesia amicably in 1960-62. About two-thirds of those eligible chose Indonesian citizenship and lost their dual national status. Although this can be considered a high proportion, it left most of Indonesia's approximately three million ethnic Chinese aliens.

During these same years, as the treaty was being implemented, a movement of young Indonesian citizens of Chinese descent worked to popularize the idea of assimilation among the ethnic Chinese and to urge the Indonesian government to remove the legal obstacles to assimilation which still existed. The strongest community organization among Indonesians of Chinese descent opposed them; however they ohtained some support from leading Indonesians, especially the military. The work of the assimilationists bore fruit only after the attacks against ethnic Chinese in 1965 and 1966, in the wake of the attempted coup attributed to the Communist Party (PKI) and the subsequent break in Indonesian diplomatic relations with Peking.

The anti-Chinese violence in the months following with coup attempt of September 30-October 1, 1965 probably surpassed all previous outbreaks in Indonesian history. It resulted in the death of several thousand Chinese, primarily but not exclusively aliens, and the confiscation or destruction of their businesses and other property ${ }^{25}$. In 1966 followed a sobering-up and a reevaluation of the position of the Chinese minority. More stringent measures were applied to exclude alien influence; Chinese-language schools, even for Chinese nationals, had to shut their doors; while removal of China's diplomatic missions closed another channel of communication with the Chinese mainland; the Chinese-language press also virtually disappeared. "National" or Indonesian-language schools dominated by ethnic Chinese, some of which had been established as successors to the Chinese-language schools closed down in 1957, were also placed under new management. "Exclusive" Chinese organizations, in particular those which might have a political content, were closed, and laws were changed to facilitate the legal adoption of Indonesian names by ethnic Chinese during a two-year period. The several thousand who took advantage of the latter procedure may well have been acting out of fear or intimidation as much as out of love for Indonesian culture, but with this and the other measures outlined above, much of the program proposed by the young assimilationist group since 1960 had been accomplished and their organization virtually disappeared from the Indonesian scene.

At the same time, a small step was made in integrating the alien Chinese, since 1962 the majority among ethnic Chinese in Indonesia. Deprived of their autonomous cultural and organizational life, above all of their schools, and for the most part unwilling or unable to return to China (if indeed they had ever been in China), they now had a better chance to acquire Indonesian citizenship through naturalization. Although many were able to take advantage of more generous

24 Aliens were forbidden to engage in retail trade in rural areas of Indonesia in 1959; coupled with this, as mentioned in the text above, was a prohibition on alien residence in rural areas of certain provinces. Several thousand aliens, nearly all of them Chinese, were forcibly expelled from rural areas and small towns of West Java in 1959-60, and Indonesian-Chinese relations nearly reached the breaking point over the treatment of Chinese nationals.

25 The total number of victims of the violent reaction against the PKI ran into the hundreds of thousands. 
regulations on the issue; others found their applications bogged down in bureaucratic disorder ${ }^{26}$.

Since the earliest days of Chinese settlement in Java under VOC rule, the Chinese minority has displayed considerable resistance to assimilation. With the changes in policy of the recent years, however, the possibility of integration and assimilation of that minority, especially of the so-called Peranakan element, has increased. Certainly the Chinese minority, even on Java where conditions are most favorable, will not disappear within the next generation or two. Despite a more favorable official attitude than that under the Dutch regime, indigenous resistance to full acceptance of the Chinese is still a retardant to assimilation. The presence of the many alien Chinese, sentimental ties to a resurgent China and family connections in the Chinese trading centers elsewhere in Southeast Asia are, for many ethnic Chinese, too great a pull away from Indonesia. But given favorable economic conditions and a reasonably stable political situation, many young ethnic Chinese will choose to melt, as did their distant relatives in the Siam of the 19th century, into indigenous society.

26 See the author's "Die chinesische Minderheit im politischen Leben Indonesiens," Zeitschrift für Politik, September 1968, pp. 337-352 and a forthcoming study on Indonesia's Chinese minority by J. A. C. Mackie and Charles Coppel of Monash University (Australia). 


\section{Sri Lanka (Ccylon) - The New Republican Constitution}

By K. M. de Silva

The new constitution of Sri Lanka, replacing the former British-sponsored Soulbury system, was promulgated on 22 May, 1972. It ought to be the proper manifestation of people's sovereignty, but it was written with a minimum of public participation. By promulgating the constitution the ruling coalition has given itself a term up to 1977, i. e. two years beyond the five year term for which it was elected in May 1970! Indeed few public events in the island's recent history attracted less public interest than the inauguration of a constitution which was trumpeted to mark the transition from British Dominion Status to a "genuine" independence which in the very end however came out as a mere partyaffair.

There are some new features in the 1972 constitution, which are to remove the "shortcomings" of the old Soulbury-Constitution:

1. One achievement is the formal dissolution of the link with the British crown.

2. Elimination of all clauses which safeguarded minorities against discriminatory legislation, e. g. Tamil will be excluded as an official language of Sri Lanka.

3. No more right of judicial review by the Courts over the constitutionality of legislation passed by parliament.

4. Replacement of the former bicameral legislature by the unicameral National State Assembly as an instrument of people's sovereignty.

The system now may be described as a centralised democracy in which the most dominant element is the political executive which in comparison with the former constitution has fewer built-in checks on the abuse of political power.

\section{Dutch Colonial and Indonesian Nationalist Policies toward the Chinese Minority in Indonesia}

\section{By Mary F. Somers Heidhues}

The paper explores the political organization (Kapitan system) and social role of the non-assimilated Chinese within Indonesian society (Peranakans) under colonial rule and the reasons for their resistance to assimilation. Faced with many new immigrants from China early in this century the colonial government made certain concessions (e. g. Dutch language schools) to the Chinese minority, in order to win over at least the Peranakan element. Chinese born in the Indies were recognized as Dutch subjects in 1910, in an effort to limit China's influence over that group. But the colonial authorities also restricted certain activities of the Chinese in order to protect the natives from economic "exploitation" by Chinese traders or moneylenders. The governments of independent Indonesia followed the same general line and attempted to control the economic activities of the Chinese, to restrict their access to Indonesian citizenship, and to promote indigenous businesses. Although resistance to assimilation still persists, such possibilities for Chinese with Indonesian citizenship have opened in recent years. At the same time, the alien Chinese, who have been subjected to discrimination and countless hardships, have been given limited opportunity to acquire Indonesian citizenship. Although eventual assimilation is a matter of decades, if not of generations, such changes may contribute to the erosion of the Chinese minority in Indonesia in the future. 